\title{
Lymphatic filariasis in the Caribbean region: the opportunity for its elimination and certification
}

\author{
Samuel C. Rawlins, ${ }^{1}$ Patrick Lammie, ${ }^{2}$ Tejpratap Tiwari, ${ }^{3}$ \\ Pedro Pons, ${ }^{4}$ Dave D. Chadee, ${ }^{5}$ Baltus F. J. Oostburg, ${ }^{6}$ and \\ Shiremattee Baboolal ${ }^{1}$
}

\begin{abstract}
In order to support the case for a certification of elimination of lymphatic filariasis (LF) in some Caribbean countries, we compared the prevalence of circulating Wuchereria bancrofti antigen in communities in Guyana, Suriname, and Trinidad. For the study, we assayed school children in six communities in Guyana, five communities in Suriname, and three communities in Trinidad for the prevalence of circulating W. bancrofti antigen, using a new immunochromatographic test for LF. We also assayed adults in these three countries, with a special focus on Blanchisseuse, Trinidad, where mass treatment for LF elimination had been carried out in 1981. The prevalences of W. bancrofti circulating antigen found in the school children populations ranged from $1.7 \%$ to $33.2 \%$ in Guyana and were $0.22 \%$ overall in Suriname and $0.0 \%$ in Trinidad. Among adults in two Guyana communities the prevalences were $16.7 \%$ and $32.1 \%$. The results were all negative from 211 adults in communities in the north, center, and south of Trinidad, as well as from 29 adults in Suriname. The data suggest that contrary to reports of LF endemicity from the World Health Organization, LF may no longer be present in Trinidad and may be of very low prevalence in Suriname. Trinidad and Tobago and other Caribbean nations proven negative could seek to be awarded a certificate of LF elimination. In Suriname the small localized pocket of infected persons who may serve as a reservoir of LF infection could be tested and appropriately treated to achieve LF elimination. Such LF-positive countries as Guyana should access new international resources being made available for LF elimination efforts. An adequate certification program would help identify which countries should seek the new LF elimination resources.
\end{abstract}

Characterized by the gross manifestations it causes, lymphatic filariasis

\footnotetext{
1 Caribbean Epidemiology Centre, Port of Spain, Trinidad. Send correspondence to: Dr. S.C. Rawlins, Caribbean Epidemiology Centre, 16-18 Jamaica Boulevard, P.O. Box 164, Port of Spain, Trinidad and Tobago.

2 United States of America, Centers for Disease Control and Prevention, Atlanta, Georgia, United States of America.

3 Guyana, Ministry of Health, Georgetown, Guyana.

4 Pan American Health Organization, Georgetown, Guyana.

5 Trinidad and Tobago, Ministry of Health, Port of Spain, Trinidad.

6 University of Suriname, Paramaribo, Suriname.
}

(LF) continues to be prevalent in the Caribbean region, particularly Guyana $(1,2)$ and Haiti and the Dominican Republic (3). In addition, the World Health Organization (WHO) lists Costa Rica, Suriname, and Trinidad and Tobago as still being positive for this disease (3). At the same time, other territories in the Americas have an uncertain status and have not yet been declared free of LF; these include Antigua and Barbuda, French Guiana, Guadeloupe, Panama, Puerto Rico, Saint Kitts and Nevis, and the Virgin Islands (3) (Table
1). According to $\mathrm{WHO}$ estimates, if one includes the Brazilian focus, there are some 300000 cases of Bancroftian LF in the Americas (3).

Nevertheless, WHO's assessment of LF in the Region of the Americas merits additional deliberation. Oostburg (4) showed that only a very low prevalence $-0.06 \%$ microfilaremia-was detectable among 51097 Surinamese. Nathan et al. reported (5) that LF had been eliminated from Trinidad through a mass treatment program with diethylcarbamazine (DEC), a finding later 
TABLE 1. Countries and entities of the Americas listed by the World Health Organization as being positive for lymphatic filariasis

\begin{tabular}{l}
\hline Currently infected \\
Brazil \\
Costa Rica \\
Dominican Republic \\
Guyana \\
Haiti \\
Suriname \\
Trinidad and Tobago \\
Current status uncertain ${ }^{\text {a }}$ \\
Antigua and Barbuda \\
Barbados \\
Colombia \\
Cuba \\
Dominica \\
French Guiana \\
Guadeloupe \\
Martinique \\
Montserrat \\
Panama \\
Puerto Rico \\
Saint Kitts and Nevis \\
Saint Lucia \\
Venezuela \\
Virgin Islands (British and U.S.) \\
\hline Source: (3). \\
a Current status uncertain = Countries and entities not de- \\
clared free of lymphatic filariasis (LF) by the World Health \\
Organization (WHO) and which the WHO had previously \\
listed as being positive for LF.
\end{tabular}

confirmed by Chadee et al. (6). Apart from Guyana, LF has not been reported to us at the Caribbean Epidemiology Centre (CAREC) as being present in any of our member countries in the last 10 to 15 years (Rawlins, personal observation, 1998).

It has been difficult to confirm the presence of LF in asymptomatic persons, given the nocturnal periodicity of the occurrence of Wuchereria bancrofti in the peripheral blood, and the resulting inconvenience of accessing patients. At the same time, microscopic detection is not very useful in symptomatic patients since the number of microfilariae becomes reduced with rising antibody levels over time (2). Very few laboratories in the Caribbean offer an antibody diagnostic service for LF (Rawlins, personal observation, 1998). Thus it is possible that despite clinical suspicion, both symptomatic and asymptomatic LF may exist without being specifically confirmed.
Recently, a new tool for LF diagnosis has come on the market (7). It is a rapid immunochromatographic (ICT) card test for qualitative detection of $W$. bancrofti antigen, for in vitro use, produced by the AMRAD ICT division of AMRAD Corporation Limited (Sydney, New South Wales, Australia). Both the sensitivity and specificity of the test are greater than $99 \%$. Circulating $W$. bancrofti antigens can be detected in essentially all microfilaremic subjects and in a proportion of amicrofilaremic persons with previously cryptic infections (8). In contrast, persons with lymphedema or elephantiasis are unlikely to be antigen-positive, using either the ICT card test or the more sensitive Og4C3 enzyme-linked immunosorbent assay (ELISA) (7).

The ICT card test detects $W$. bancrofti antigen in whole blood, using a polyclonal antibody and a monoclonal antibody specific for $W$. bancrofti. A fingerprick quantity $(100 \mu \mathrm{L})$ of blood is placed on the immunochromatographic card, and the results can be read in 3-15 minutes. Such a tool could be extremely useful for demonstration of the W. bancrofti antigen at any time of the day and with any accessible population. School children, for example, would be a very useful indicator group for any recent transmission of the parasite, and many children could be easily surveyed at one time. LF-positive persons could then be offered treatment with DEC or another medication, ivermectin. Both DEC and ivermectin have been shown to be very effective in reducing microfilaremia, especially when administered together, or with a single dose of the drug albendazole. DECfortified salt substituted for regular table salt over 6 to 12 months has also proved efficacious against LF (9).

In May 1997 the Fiftieth World Health Assembly called on WHO and its Member States to engage in a worldwide LF elimination program (10). SmithKline Beecham, the pharmaceutical firm that manufactures albendazole, has offered to donate all of the medication needed for such an LF elimination program. More recently, Merck and Company, Inc., the manufacturer of ivermectin, said it would expand production of this drug to support WHO's effort to eliminate LF (9).

Given these steps forward, it is all the more important for the countries in the Caribbean to take a regional approach to identifying the communities that are still endemic for LF and those where LF has been eliminated. The data coming from these new efforts could also help the Caribbean countries where LF is endemic to gain access to these newly available resources for LF elimination.

\section{MATERIALS AND METHODS}

For our study, microscopic analysis was used in Guyana, and ICT card tests were used in Guyana, Suriname, and Trinidad.

\section{Microscopic analysis}

In January-May 1998, sampling of persons for LF by microscopic methods was done in Georgetown, Guyana. At the filariasis clinic of Georgetown Public Hospital an assessment was done with two groups. One group were 407 patients reporting lymphedema, that is, pain and swelling in various lymph nodes. The second group were 119 persons who were asymptomatic, generally individuals who needed information on their LF status to enter certain employment sectors. One finger-prick blood sample for each patient was processed by routine Giemsa staining of thick blood films and microscopy for LF.

\section{Immunochromatographic card testing}

ICT filariasis tests were performed with both adults and school children in Guyana, Suriname, and Trinidad. For the tests, capillary blood was collected in uncoated capillary tubes and then immediately added to the ICT card for each subject. The tests were developed and read according to the manufacturer's instructions; Weil et al. (7) present further details on this test method. 
A random selection of children 8-11 years old was made in schools in various communities of the three countries. In addition, adult teachers from some of the schools and other persons from the communities were assayed randomly. In Trinidad, 211 asymptomatic adult general medical clinicattenders were sampled in four locations of northern Trinidad, two locations in central Trinidad, and two locations in southern Trinidad.

In Guyana, samples were taken from 575 children from six of the country's ten administrative regions and from 133 adults from two of those regions.

In Suriname, 254 school children were sampled from the north, central, and south sections of Paramaribo, which is the capital and largest city. Another 202 school children were sampled from two neighborhoods of Nickerie, a city of some 35000 on the border with Guyana. A total of 29 adults were also tested, 19 from Paramaribo and 10 from Nickerie.

In Trinidad, in addition to the 211 adults already mentioned, a total of 139 school children were tested. The children were from the previously LFendemic community of Blanchisseuse (5) and from the neighboring communities of Matelot and Grande Rivière.

In the three countries any person who tested positive received DEC treatment from a regional health office.

\section{RESULTS}

\section{Guyana}

In Guyana, the microscopy diagnosis at Georgetown Public Hospital found positive test results for only 22 (5.4\%) of the 407 patients reporting lymphedema. Conversely, 37 (31.1\%) of the 119 asymptomatic patients were shown to be positive (Table 2).

With the children in Guyana, our questions and superficial observations revealed that none of them was symptomatic, though this was not a criterion for participation in the study.

However, with the ICT testing, antigen-positive school children were
TABLE 2. Microscopic microfilaria screening results, Georgetown Hospital filariasis clinic, Georgetown, Guyana, 1998

\begin{tabular}{lccr}
\hline & $\begin{array}{c}\text { Number of } \\
\text { samples }\end{array}$ & \multicolumn{2}{c}{ Positive samples } \\
\cline { 3 - 4 } Patient status & assayed & No. & $\%$ \\
\hline Lymphedema $^{\text {a }}$ & 407 & 22 & 5.4 \\
Asymptomatic & 119 & 37 & 31.1 \\
\hline
\end{tabular}

a Patients who reported pain and swelling in various lymph nodes.

found in all six of the regions where that testing method was used (Table 3). Positivity rates for Guyana's coastal urban centers ranged from $20.0 \%$ in New Amsterdam to 33.2\% in Georgetown.

Conversely, in such noncoastal or largely rural communities as Suddie, Bartica, and Fort Wellington, the prevalence rates were $2.5 \%$ or less. With the adults screened in Georgetown and New Amsterdam, the positivity rates were $16.7 \%$ and $32.1 \%$, respectively.

\section{Trinidad}

In sharp contrast to Guyana, there were no children found positive among the 139 students tested in the northern part of Trinidad (Table 4). Similarly, all the Trinidad adults proved negative, in all three parts of the island.
Some of the negative adults in Blanchisseuse, in northern Trinidad, were known to have been treated with DEC as part of a mass elimination program conducted in 1981 (5).

\section{Suriname}

Of the 456 children tested in Suriname, only 1 antigen-positive student was found, a child from the Nickerie area (Table 5). Our community nurses indicated that this girl lived in a community that was inhabited by Guyanese immigrants and that the student had visited Guyana within the preceding 6 months. None of the adult Surinamese was found to be positive for the circulating LF antigen.

\section{DISCUSSION}

The LF endemicity status of the Dominican Republic, Guyana, and Haiti has already been established (1-3). Nevertheless, the fact that CAREC and other institutions have not received positive reports for other Caribbean countries cannot be assumed to indicate negative endemicity, since asymptomatic persons are not routinely examined in Caribbean countries (Rawlins, personal observation, 1998). At the same time, microscopy may wrongly rule symptomatic patients negative for

TABLE 3. Prevalence of circulating Wuchereria bancrofti antigen in Guyana communities as indicated by immunochromatographic card testing, 1998

\begin{tabular}{|c|c|c|c|c|c|c|c|c|}
\hline \multirow{2}{*}{$\begin{array}{l}\text { Administrative } \\
\text { region } \\
\text { number }\end{array}$} & \multirow{2}{*}{$\begin{array}{l}\text { Estimated } \\
\text { percentage of } \\
\text { the national } \\
\text { population }\end{array}$} & \multirow[b]{2}{*}{$\begin{array}{c}\text { Survey } \\
\text { communities }\end{array}$} & \multicolumn{3}{|c|}{ Children } & \multicolumn{3}{|c|}{ Adults } \\
\hline & & & $\begin{array}{c}\text { No. } \\
\text { tested }\end{array}$ & $\begin{array}{c}\text { No. } \\
\text { positive }\end{array}$ & $\begin{array}{c}\% \\
\text { positive }\end{array}$ & $\begin{array}{c}\text { No. } \\
\text { tested }\end{array}$ & $\begin{array}{c}\text { No. } \\
\text { positive }\end{array}$ & $\begin{array}{c}\% \\
\text { positive }\end{array}$ \\
\hline 1 & 2.6 & $\mathrm{NT}^{\mathrm{a}}$ & $\ldots$ & $\ldots$ & $\ldots$ & $\ldots$ & $\ldots$ & $\ldots$ \\
\hline 2 & 5.9 & Bartica, Suddie & 40 & 1 & 2.5 & NT & $\ldots$ & $\ldots$ \\
\hline 3 & 12.7 & Vreed-en-Hoop & 106 & 31 & 29.2 & NT & $\ldots$ & $\ldots$ \\
\hline 4 & 41.4 & Georgetown & 196 & 65 & 33.2 & 24 & 4 & 16.7 \\
\hline 5 & 6.9 & Fort Wellington & 60 & 1 & 1.7 & NT & $\ldots$ & $\ldots$ \\
\hline 6 & 19.9 & New Amsterdam & 110 & 22 & 20.0 & 109 & 35 & 32.1 \\
\hline 7 & 2.1 & NT & $\ldots$ & $\ldots$ & $\ldots$ & $\ldots$ & $\ldots$ & $\ldots$ \\
\hline 8 & 0.8 & NT & $\ldots$ & $\ldots$ & $\ldots$ & $\ldots$ & $\ldots$ & $\ldots$ \\
\hline 9 & 2.1 & NT & $\ldots$ & $\ldots$ & $\ldots$ & $\ldots$ & $\ldots$ & $\ldots$ \\
\hline 10 & 5.4 & Linden & 63 & 6 & 9.5 & NT & $\ldots$ & $\ldots$ \\
\hline Total & & & 575 & 126 & 21.9 & 133 & 39 & 29.3 \\
\hline
\end{tabular}


TABLE 4. Prevalence of circulating Wuchereria bancrofti antigen in Trinidad communities as indicated by immunochromatographic card testing, 1998

\begin{tabular}{|c|c|c|c|c|c|}
\hline \multirow[b]{2}{*}{ Region } & \multirow[b]{2}{*}{ Survey location } & \multicolumn{2}{|c|}{ Children } & \multicolumn{2}{|c|}{ Adults } \\
\hline & & $\begin{array}{l}\text { No. } \\
\text { tested }\end{array}$ & $\begin{array}{c}\text { No. } \\
\text { positive }\end{array}$ & $\begin{array}{l}\text { No. } \\
\text { tested }\end{array}$ & $\begin{array}{c}\text { No. } \\
\text { positive }\end{array}$ \\
\hline \multirow[t]{4}{*}{ North } & Blanchisseuse & 69 & 0 & 68 & 0 \\
\hline & Matelot & 38 & 0 & 17 & 0 \\
\hline & Grand Riviere & 32 & 0 & 25 & 0 \\
\hline & Maraval & $\mathrm{NT}^{\mathrm{a}}$ & $\ldots$ & 21 & 0 \\
\hline \multirow[t]{2}{*}{ Central } & Freeport & NT & $\ldots$ & 25 & 0 \\
\hline & Couva & NT & $\ldots$ & 24 & 0 \\
\hline \multirow[t]{2}{*}{ South } & Pleasantville & NT & $\ldots$ & 21 & 0 \\
\hline & La Brea & NT & $\ldots$ & 10 & 0 \\
\hline Total & & 139 & 0 & 211 & 0 \\
\hline
\end{tabular}

${ }^{\mathrm{a}} \mathrm{NT}=$ Not tested.

TABLE 5. Prevalence of Wuchereria bancrofti circulating antigens in Suriname communities as indicated by immunochromatographic card testing, 1998

\begin{tabular}{|c|c|c|c|c|c|c|c|}
\hline \multirow[b]{2}{*}{ Region } & \multirow[b]{2}{*}{ Survey location } & \multicolumn{3}{|c|}{ Children } & \multicolumn{3}{|c|}{ Adults } \\
\hline & & $\begin{array}{l}\text { No. } \\
\text { tested }\end{array}$ & $\begin{array}{c}\text { No. } \\
\text { positive }\end{array}$ & $\begin{array}{c}\% \\
\text { positive }\end{array}$ & $\begin{array}{l}\text { No. } \\
\text { tested }\end{array}$ & $\begin{array}{c}\text { No. } \\
\text { positive }\end{array}$ & $\begin{array}{c}\% \\
\text { positive }\end{array}$ \\
\hline Paramaribo & $\begin{array}{l}\text { South (Saron) } \\
\text { North (Renckewitz) } \\
\text { Central (M. Immaculate) }\end{array}$ & $\begin{array}{l}72 \\
97 \\
85\end{array}$ & $\begin{array}{l}0 \\
0 \\
0\end{array}$ & $\begin{array}{l}0 \\
0 \\
0\end{array}$ & $\begin{array}{r}13 \\
1 \\
5\end{array}$ & $\begin{array}{l}0 \\
0 \\
0\end{array}$ & $\begin{array}{l}0 \\
0 \\
0\end{array}$ \\
\hline Nickerie & $\begin{array}{l}\text { St. Clara } \\
\text { O.S.I. New Nickerie }\end{array}$ & $\begin{array}{r}107 \\
95\end{array}$ & $\begin{array}{l}1 \\
0\end{array}$ & $\begin{array}{c}0.9 \\
0\end{array}$ & $\begin{array}{l}N T^{a} \\
10\end{array}$ & $\begin{array}{l}\ldots \\
0\end{array}$ & $\begin{array}{l}\ldots \\
0\end{array}$ \\
\hline Total & & 456 & 1 & 0.2 & 29 & 0 & 0 \\
\hline
\end{tabular}

${ }^{\mathrm{a}} \mathrm{NT}=$ Not tested.

LF. Requests for antibody studies are only rarely forwarded to CAREC and other laboratories, and antibody testing does not really exclude LF as a cause of lymphedema. Clinical diagnosis of LF based on lymphangitis, lymphadenitis, or similar symptoms can be unreliable, since such symptoms may be due to a range of other causes. Therefore, the sensitivity and specificity of the clinical examination method may be classified as being low to very low (7).

There are many convenient aspects to using the ICT card test (10). Because there is no known nocturnal periodicity of the circulating antigen in peripheral blood-unlike with the circulating microfilariae-the ICT test can be administered at any time of the day or night. In addition, cohorts of any con- venient population may be sampled, since there is no advantage or value in sampling symptomatic persons for antigen status. Thus, the sampling of school children in a community can be a useful epidemiological strategy.

The high proportion of Guyanese school children and adults found to be ICT-positive for $W$. bancrofti antigenemia is remarkable. With positive results from all six of the administrative regions where testing was done, this indicates that $92 \%$ of the population of Guyana reside in areas where there is a risk of filarial infection. Even if only a small portion of the children found positive eventually develop symptoms, this proportion is unacceptably high and calls for intervention by public health authorities. It is clear that the whole community is at risk, and that an appropriate response would be a mass intervention of the type recommended by Ottesen et al. $(9,10)$. Such a communitywide treatment program may involve the coadministration of ivermectin and albendazole or a onedrug regimen, such as ivermectin alone. Such treatment is known to reduce blood microfilariae by $99 \%$ for a full year, and this reduction of microfilarial loads could interrupt transmission (10). DEC-fortified salt substituted for regular table salt for 6-12 months could also be efficacious (9).

In Suriname, the $0.22 \%$ prevalence of $W$. bancrofti antigenemia that we found with ICT testing with children was similar to the $0.06 \%$ prevalence that Oostburg (4) had reported with microscopic studies. Most of the positivity that Oostburg detected was among communities of immigrant Guyanese guest workers. Given that the one positive child we found lived in a community inhabited by Guyanese immigrants and that she had visited Guyana in the preceding 6 months, it is likely that it was an imported case or that there was a low level of LF endemicity in that Guyanese community in Suriname. An appropriate public health response would be intensive testing in such immigrant communities and the treatment of individuals found to be positive. Such an elimination of LF reservoirs could lead to the complete cessation of LF transmission in Suriname.

The findings from Trinidad were radically different from those in $\mathrm{Gu}$ yana, with none of the child or adult Trinidadians found positive with the ICT testing. Even the small remaining numbers of residents of northern Trinidad who were treated with DEC during the mass elimination exercise in 1981 were antigen-negative.

Our findings, combined with the earlier research by Nathan et al. (5) and Chadee et al. (6), raise questions about the WHO endemicity assessment for Trinidad $(3,10)$. These results also call into question the LF status of some countries previously reported to be of uncertain LF status but not actually declared to be free of LF by the 
WHO (Table 1). Many of the island countries of the Caribbean have not requested any LF diagnoses or reported any LF disease for a number of years. With those countries, there is a need to review their cases, with a view to demonstrating the absence of LF and certifying these countries to be free of this disease.

There is a need to systematically assess LF and certify its absence for Caribbean countries. However, this process will require some time and patience. WHO representatives met in Atlanta, Georgia, United States of America, in early September 1998 to consult on epidemiologic approaches to LF elimination and its assessment, monitoring, and certification (11). Those representatives indicated that a country could apply for certification of LF elimination only after all administrative units within the nation had achieved a cumulative 5-year incidence of infection of less than $0.1 \%$, based on antigen testing. Many small countries with limited health resources may not be inclined to dedicate that level of resources to demonstrate what they think they already know, that is, that there is no longer any LF within their borders. Nevertheless, the data coming from a certification program could strengthen $\mathrm{Ca}$ - ribbean nations' requests to participate in the LF elimination program that the Fiftieth World Health Assembly called for, and also make it easier for those countries to access the new international support that is being made available for these elimination efforts.

Acknowledgements. We are grateful to all the subjects who participated in the studies in Guyana, Suriname, and Trinidad. We also wish to thank all the health care workers in the three countries who participated in these studies.

\section{REFERENCES}

1. Nathan MB, Stroom V. Prevalence of Wuchereria bancrofti in Georgetown, Guyana. Bull Pan Am Health Organ 1990;24:301-306.

2. Rawlins SC, Chaillett P, Ragoonanansingh RN, Baboolal S, Stroom V. Microscopical and serological diagnosis of Wuchereria bancrofti. West Indian Med J 1994;43(3):75-79.

3. World Health Organization. Lymphatic filariasis: the disease and its control. Geneva: WHO; 1992. (WHO Technical Report Series \#821).

4. Oostburg BFJ. Is Wuchereriasis a disappearing disease in Suriname? Acta Leiden 1985; 53:37-50.

5. Nathan MB, Beckles G, Tikasingh ES, Hamilton PJ, Monteil S. Parasitology and clinical studies of Wuchereria bancrofti and Mansonella ozzardi in coastal north Trinidad, W.I. West Indian Med J 1982;31(4):168-176.
6. Chadee DD, Tilluckdharry CC, Rawlins SC, Doon $R$, Nathan MB. Mass chemotherapy with diethylcarbamazine for the control of filariasis: a twelve-year follow-up in northern Trinidad, including observations on Mansonella ozzardi. Am J Trop Med Hyg 1995; 52(2):174-176.

7. Weil GT, Lammie PJ, Weiss N. The ICT filariasis test: a rapid-format antigen test for diagnosis of Bancroftian filariasis. Parasitol Today 1997;13:401-404.

8. Lammie PJ, Hightower AW, Eberhard ML. Age-specific prevalence of antigenemia in a Wuchereria bancrofti-exposed population. Am J Trop Med Hyg 1994;51(3):348-355.

9. Ottesen EA, Ismail MM, Horton J. The role of albendazole in programmes to eliminate lymphatic filariasis. Parasitol Today 1999;15: 382-386.
10. Ottesen EA, Duke BOL, Karame M, Behbehari K. Strategies and tools for the control/ elimination of lymphatic filariasis. Bull WHO 1997;75(6):491-503.

11. World Health Organization, Communicable Diseases, Communicable Diseases Eradication and Elimination, Filariasis Elimination Program. Report of a WHO informal consultation on epidemiologic approaches to lymphatic filariasis elimination: initial assessment, monitoring, and certification, Atlanta, Georgia, USA, 2-4 September 1998. Geneva: WHO; 1999. (Publication WHO/FIL/99.195).

Manuscript received on 29 September 1999. Revised version accepted for publication on 17 February 2000. 
RESUMEN Con el fin de documentar la posibilidad de certificar la eliminación de la filariasis linfática (FL) en algunos países del Caribe, hemos comparado la prevalencia del antígeno circulante de Wuchereria bancrofti en comunidades de Guyana, de Suriname y

Filariasis linfática en la región del Caribe: la oportunidad para eliminarla y certificar dicha eliminación de la isla de Trinidad. Para ello, utilizamos una nueva prueba inmunocromatográfica de FL en escolares de seis comunidades de Guyana, cinco de Suriname y tres de la isla de Trinidad. También estudiamos adultos de los tres países, centrándonos especialmente en Blanchisseuse, Trinidad, donde en 1981 se llevó a cabo un tratamiento masivo para la eliminación de la FL. La prevalencia del antígeno circulante de Wuchereria bancrofti en los escolares osciló entre 1,7 y 33,2\% en Guyana; en Suriname la prevalencia global fue de $0,22 \%$ y en Trinidad de $0,0 \%$. En los adultos de dos comunidades de Guyana las cifras de prevalencia fueron de 16,7 y $32,1 \%$. Los resultados de la prueba fueron negativos en los 211 adultos de comunidades del norte, centro y sur de Trinidad, así como en los 29 adultos de Suriname. Los resultados obtenidos indican que, al contrario de lo que afirman los informes de la Organización Mundial de la Salud (OMS) sobre la endemicidad de la FL, la enfermedad parece haber desaparecido en Trinidad y tener una prevalencia muy baja en Suriname. Trinidad y Tabago y otros países del Caribe en los que se demuestre la ausencia de la enfermedad podrían obtener un certificado de eliminación de la FL. En Suriname, la pequeña y localizada bolsa de personas infectadas que actuarían como reservorio podrían ser investigadas y tratadas con el fin de conseguir la eliminación de la enfermedad. Los países donde todavía hay FL, como Guyana, podrían acceder a los nuevos recursos internacionales como parte de los esfuerzos para la eliminación de la FL. Un programa de certificación adecuado ayudaría a identificar cuáles son los países que deberían buscar estos nuevos recursos para la eliminación de la LF. 